\title{
HORMONAL PROFILES OF BLOOD PLASMA ASSOCIATED ESTRUS SYNCHRONIZATION USING DIFFERENT CONCENTRATION OF MAP AND ECG IN BARKI EWES
}

\author{
MOHAMMED, KM. ${ }^{1}$; FARAG, BF. ${ }^{3}$; DAGHASH, HA. ${ }^{2}$ and AZAB, MM. ${ }^{3}$ \\ ${ }^{1}$ Animal Reproduction Research Institute (ARRI), Agriculture Research Center (ARC), Egypt \\ ${ }^{2}$ Faculty of Agriculture, Assiut University, Egypt \\ ${ }^{3}$ Faculty of Agriculture, Al-Azhar University, Egypt
}

Received: 6 November 2016; Accepted: 19 December 2016

\begin{abstract}
The current study aimed to characterize the plateau patterns of plasma progesterone in the peripheral circulation during the application of vaginal sponge impregnated with different concentrations of medroxyprogesterone acetate (MAP) and co-treated without and with different doses of equine chorionic gonadotropin (eCG) and its effects on some items of reproductive performance. Determination the onset surges (time and level) of LH and estradiol-17 $\beta$ were also aimed in the study as a necessary pinpoint to the time of ovulation after MAP spongeeCG treatment. Forty Barki ewes were randomly allocated into 2 main groups (A \& B) of equal numbers ( $\mathrm{n}=20$ /group). Groups A and B were treated with vaginal sponges containing 25 and $50 \mathrm{mg}$ MAP, respectively. On day of sponge's withdrawal, ewes of each main group were randomly reassigned according to eCG dose into three subgroups (1, 2 and 3). Groups A1 and B1 ( $=6$ each group), served as control, without eCG injection, while groups A2 and B2 (n=7/subgroup) were injected at sponge removal with 300 IU/eCG, whereas, groups A3 and B3 ( $\mathrm{n}=7 /$ subgroup) were injected with 500 IU/eCG. Blood samples were taken immediately before sponge insertion and after the placement subsequently every 2 days and continued to the end of sponge application to studying the plateau pattern of progesterone in the peripheral circulation. Nine hours after sponge removal to $74 \mathrm{~h}$ latter, blood samples were also taken every $3 \mathrm{~h}$ and $6 \mathrm{~h}$ for determination $\mathrm{LH}$ and estradiol-17 $\beta$ surges, respectively. The time to onset estrus (h), estrus duration, pregnancy and lambing rates $(\%)$ were recorded as reproductive performance measuring related to the study. The started level of plasma progesterone in group A increased gradually with level reaching to its maximum level on days 6 and 8 of sponge application and then rapidly decreases reaching to minimum level on day of sponge removal. On contrast, the patterns of plasma progesterone changes in group B were forcefully increased but with slightly high level from the beginning reaching its highest concentration on day 6 and day 8, then decline gradually to reach lower level on the day of sponge withdraw. The mean time from sponge withdraw to $\mathrm{LH}$ and estradiol-17 $\beta$ surges were significantly shorter $(\mathrm{P}<0.05)$ in-group A than $\mathrm{B}$ and significantly longer $(\mathrm{P}<0.01)$ in group A1B1 than other eCG treated groups. Neither MAP nor eCG have significant effects on LH concentration, while, eCG have positive effects on the concentration of estradiol-17 $\beta$. Generally, the hormonal plateau patterns of group A were associated with acceleration the time to onset estrus with high pregnancy rate. In conclusion, the protocols used for estrus synchronization in sheep are associated with different plateau patterns of circulating reproductive hormones and subsequently affect reproductive performance.
\end{abstract}

Key words: Sheep, Estrus synchronization, Reproductive performance, LH, Progesterone, Estradiol.

\section{INTRODUCTION}

Estrous synchronization is a valuable reproductive technique which has been successfully applied to reinforce reproductive efficiency in small ruminants (Kusina et al., 2000, Mohammed et al., 2016). Intravaginal sponges/devices impregnated with

Corresponding author: Dr. MOHAMMED KM

E-mail address:kamel14@hotmail.com

Present address: Animal Reproduction Research Institute (ARRI),

Agriculture Research Center (ARC), Egypt synthetic progestagen such as fluorogestone acetate (FGA) or medroxy progesterone acetate (MAP) over periods of 7-12 days, have been widely used in sheep accompanied by an administration of equine chorionic gonadotropin (eCG) at the time of sponge removal to induce a more precise synchronization of estrus and ovulation during the breeding and nonbreeding seasons (Bartlewski et al., 1999; Ataman et al., 2006; Moakhar et al., 2012; and Sareminejad et al., 2014). The levels of progestagens dose are the most important factors leading to fertility raterepression (Moradikor et al., 2013). There are 
suggestions that commercial formulation of MAP sponges could be reduced to $25 \%$ without affecting the estrus response and sufficient to achieve optimal fertility (Simonetti et al., 2000; Ungerfeld, 2003 and Kasikci et al., 2011). Contrary, Crosby et al. (1991) postulated that a high level of progestagen is necessary for acceptable fertility at the synchronized estrus.

The circulating level of progesterone are released then declined over the time while the sponge in the vagina (Amer and Hazzaa, 2009). The initial release of progestagen from intravaginal sponges is high and peaks occurs within two (Yavuzer, 2005) three (Wheaton et al., 1993) five days (Satterfield, 2004) of sponge administration and declined gradually as the efficacy of the sponge decreases during the remaining period reached to minimal levels at the day of sponge withdrawal (Husein et al., 1998 and Husein and Kridi, 2002) or at the day of estrus (Kaya et al., 2013). Contrary, Greyling et al. (1997) and Kasikci, et al. (2011) they found the circulating progesterone were similar on the 1st, 4th, 7th, 10th, and 13th day after sponge insertion with no differences.

The preovulatory LH surge (timing and concentration) and relatively estradiol, both hormones are taken as being indicative of ovulation (Ashwag and Mohamed Nour, 2015). The LH surge is highly correlated with the time of ovulation as it stimulates ovulation, which occurs about 14 hours after the LH peak, or 24 hours after the beginning of estrus (Pierson et al., 2001; Alvarez et al., 2007). This estimation time of ovulation could be of great assistance in timing AI or natural mating with subsequently increasing fertilization rate in ovine breeding programs (Kennedy, 2012 and Ashwag et al., 2015). The effectiveness of different levels of MAP co-treated without and with different doses of eCG on blood profiles of reproductive hormones were aimed in this study. Evaluation the efficiency of some items related to reproductive performance were also aimed in the study. The present study is a part of MD Thesis in which estrus synchronization was applied using MAP impregnated sponge with two different concentrations and co-treated with different doses of eCGto improve the reproductive efficiency of ewes under Egyptian conditions. Barki sheep was targeted in this study where it's the most important breeds among the native sheep breeds in Egypt and characterized with high meat quality and well adapted to poor pasture and harsh desert conditions (El-Wakil et al., 2008).

\section{MATERIALS AND METHODS}

\section{Location and animal's management}

The study was carried out on forty Barki ewes weighing $35-45 \mathrm{~kg}$ and aging $3-5$ years. The animals were multiparous, non-pregnant, non-lactating, clinically healthy, and free from reproductive disorders. A maintenance ration containing Egyptian clover plus concentrate mixture with $16.6 \%$ crude protein, water and mineral supplement was available ad-libitum. The study was performed during spring season at Animal Reproduction Research Institute (ARRI), Giza province (located at latitude of $30^{\circ} 00^{\prime} 29^{\prime \prime} \mathrm{N}$, longitude of $31^{\circ} 12^{\prime} 39^{\prime \prime} \mathrm{E}$, and altitude of $30 \mathrm{~m}$ above sea level). Ewes were raised under traditional management and natural field conditions of Egypt.

\section{Experimental design and treatment schedule}

The animals under study were randomly allocated into 2 main groups (A \& B) of equal numbers ( $n=20$ /group). Groups $A$ and $B$ were treated with vaginal sponges containing 25 and $50 \mathrm{mg}$ MAP (DEPO-PROVERA, Pfizer manufacturing, Puurs, Belgium), respectively, for 14 days. On day 14 (day of sponges withdrawal) ewes of each main group were randomly reassigned according to eCG dose into three subgroups (1, 2 and 3). Groups A1 and B1 ( $n=6 /$ subgroup), served as control, without eCG injection, while groups $\mathrm{A} 2$ and $\mathrm{B} 2 \mathrm{n}=7$ ewes for each) were injected intramuscularly (IM) at the time of sponge removal with 300 IU/eCG (Gonaser, Hipra, Girona, Spain), whereas, groups A3 and B3 ( $n=7$ ewes for each) were injected with $500 \mathrm{IU} / \mathrm{eCG}$. Ewes that showed estrus were naturally mated twice with fertile rams. The time to onset estrus (h), estrus duration, pregnancy and lambing rates $(\%)$ were recorded as reproductive performance measuring related to the study. Pregnancy diagnosis was performed by trans-rectal ultrasonography using a real time B-Mode ultrasound equipped with a stiffened 7.5 MHz linear array trans-rectal probe (Pie Medical LC 100, Netherlands) on day 35-40 following the mating. Experimental design and treatment schedule are shown in table 1 . 
Table 1: Experimental design for estrus synchronization and treatment.

\begin{tabular}{|c|c|c|}
\hline $\begin{array}{l}\text { Main groups } \\
\text { (MAP levels) }\end{array}$ & $\begin{array}{l}\text { Sub groups } \\
\text { (eCG doses) }\end{array}$ & NO. of treated ewes \\
\hline \multirow{4}{*}{$\begin{array}{l}\text { Group A } \\
(25 \mathrm{mg})\end{array}$} & $\begin{array}{c}\mathrm{A} 1 \\
\text { (Without eCG; control) }\end{array}$ & 6 \\
\hline & $\begin{array}{c}\text { A2 } \\
(300 \mathrm{IU})\end{array}$ & 7 \\
\hline & $\begin{array}{c}\mathrm{A} 3 \\
(500 \mathrm{IU}) \\
\end{array}$ & 7 \\
\hline & Total A & 20 \\
\hline \multirow{4}{*}{$\begin{array}{l}\text { Group B } \\
(50 \mathrm{mg})\end{array}$} & $\begin{array}{c}\text { B1 } \\
\text { (Without eCG; control) }\end{array}$ & 6 \\
\hline & $\begin{array}{c}\text { B2 } \\
(300 \mathrm{IU})\end{array}$ & 7 \\
\hline & $\begin{array}{c}\text { B3 } \\
(500 \mathrm{IU}) \\
\end{array}$ & 7 \\
\hline & Total B & 20 \\
\hline
\end{tabular}

\section{Blood sampling for hormonal assay}

Blood samples were collected via a jugular vein into vaccutainers tubes containing EDTA. For studying the progesterone level in the peripheral circulation, blood samples were taken immediately before sponge insertion and after the placement subsequently every 2 days and continued to the end of sponge application. Nine hours after sponge removal blood samples were taken from all treated groups every $3 \mathrm{~h}$ and $6 \mathrm{~h}$ for LH and estradiol-17 $\beta$ assay, respectively according to Ashwag et al. (2015). The onset of LH surge was defined according to Evans et al. (1997) and Van Cleeff et al., 1998). LH surge defined as the first sample in which $\mathrm{LH}$ concentrations exceeded two times the pre-surge baseline and remained at this level or above for the next one or more samples. The pre-surge baselines for $\mathrm{LH}$ were calculated as the mean of the pre-surge hormone concentrations. Blood samples were centrifuged within 30 minutes of collection at $3000 \mathrm{rpm}$ for 15 minutes. Plasma was pipetted into $2 \mathrm{~mL}$ Eppendorf tubes using sterilized plastic disposable Pasteur pipettes, and then stored at $-20{ }^{\circ} \mathrm{C}$ until assayed for progesterone, $\mathrm{LH}$ and estradiol-17 $\beta$.

\section{Hormonal assay}

Progesterone and Estradiol-17 $\beta$ level were assayed using a commercially available ELISA kit (Enzyme immunoassay for the quantitative determination of progesterone and estradiol concentrations; BIOTECH, Inc. Foster City, USA) according to the instructions provided by the manufacturer. Luteinizing Hormone (LH)level was assayed by sheep Luteinizing Hormone using ELISA Kit (Sun long Biotech CO., LTD. catalogue number SL 00040 $\mathrm{Sp})$ as described by manufacture.

\section{Statistical Analysis}

The SPSS version 10.0.1 (Statistical Package for the Social Sciences) software was used for all data statistical analyses. Hormonal assay were statistically analyzed using analysis of variance (ANOVA), with the GLM-General factorial procedure of SPSS and post hoc mean comparisons were performed using Duncan test with significance level at $\mathrm{P}<0.05$.

\section{RESULTS}

The pattern of progesterone level in the peripheral circulation has been investigated during the application of vaginal sponge which containing different concentrations of MAP. As shown in Figure 1 , the principled mean levels of plasma progesterone before sponge insertion were $1.52 \pm 0.24$ and $1.67 \pm 0.29 \mathrm{ng} / \mathrm{mL}$ for group A (25 mg MAP) and group B (50 mg MAP), respectively, with no significant differences between groups. However, the started level of plasma progesterone in group (A) increased gradually reaching to its maximum levels on days $6(1.97 \pm 0.49)$ and $8(2.00 \pm 0.45)$ and then rapidly decreases until reach to its minimum level on day $14(1.08 \pm 0.20)$. On the other side, the patterns of plasma progesterone changes in group $\mathrm{B}$ were somewhat likewise group $\mathrm{A}$, but in group $\mathrm{B}$, the beginning level was $1.67 \pm 0.29 \mathrm{ng} / \mathrm{mL}$ then forcefully increased to reaches $2.40 \pm 0.40$ and $2.47 \pm 0.36 \mathrm{ng} / \mathrm{mL}$ on day 6 and day 8, respectively, then decline gradually to reach lower level $(1.61 \pm 0.33 \mathrm{ng} / \mathrm{mL})$ on the day of sponge withdraw (Figure 1). 


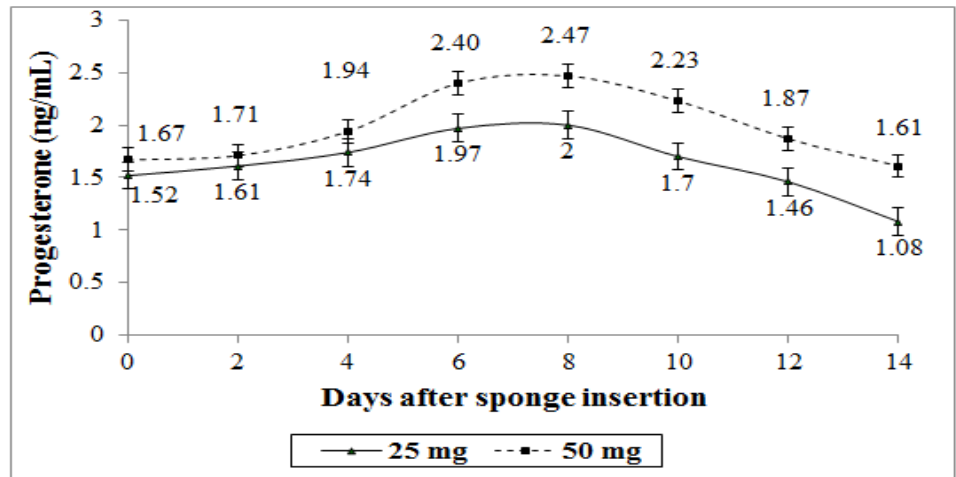

Figure 1: Plasma progesterone levels during application of vaginal sponge containing 25 and 50mg medroxyprogesterone acetate (MAP) for estrus synchronization in Barki ewes (Mean $\pm \mathrm{SE}$ )

Figure 2 shows plasma progesterone changes as percentages in relation to day of sponge insertion. In group $\mathrm{A}$, the plasma progesterone concentration increased gradually from beginning level to reaches its peak at days 6 and 8 with increasing rates 29.34 and $32.11 \%$ above starting level $(1.52 \pm 0.24 \mathrm{ng} / \mathrm{mL})$ respectively, then decreased dramatically to be below the beginning level with $-28.95 \%$ at day 14 (day of sponge withdraw). On the other side, the plasma progesterone in group $\mathrm{B}$ showed progressively increases from the started plasma progesterone level $(1.67 \pm 0.29 \mathrm{ng} / \mathrm{mL})$ reaching maximum levels with $43.62 \%$ and $47.52 \%$ increases at days 6 and 8 of sponge insertion, respectively, then dropped relatively slowly than group A to reach its minimum level on day 14 with $-3.42 \%$ below started level (Figure 2).

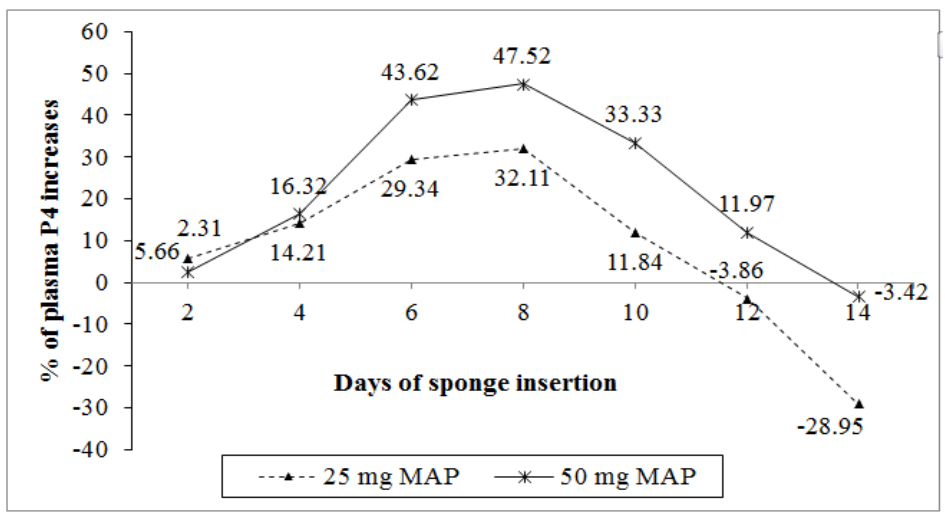

Figure 2: Effect of MAP concentration in the vaginal sponge on Percentages of plasma progesterone plateau related to day of insertion and subsequent days.

Figure 3 shows that, aside of eCG effect, the mean time from sponge withdraw to $\mathrm{LH}$ surge was significantly shorter $(\mathrm{P}<0.05)$ in-group A than $\mathrm{B}$ $(42.89 \pm 4.07 \mathrm{~h}$ vs $54.07 \pm 3.49 \mathrm{~h})$ and the concentrations of $\mathrm{LH}$ surge were $21.83 \pm 1.94 \mathrm{mIU} / \mathrm{mL}$ and $19.80 \pm 1.78 \mathrm{mIU} / \mathrm{mL}$, for groups $\mathrm{A}$ and $\mathrm{B}$, respectively with no significant differences.

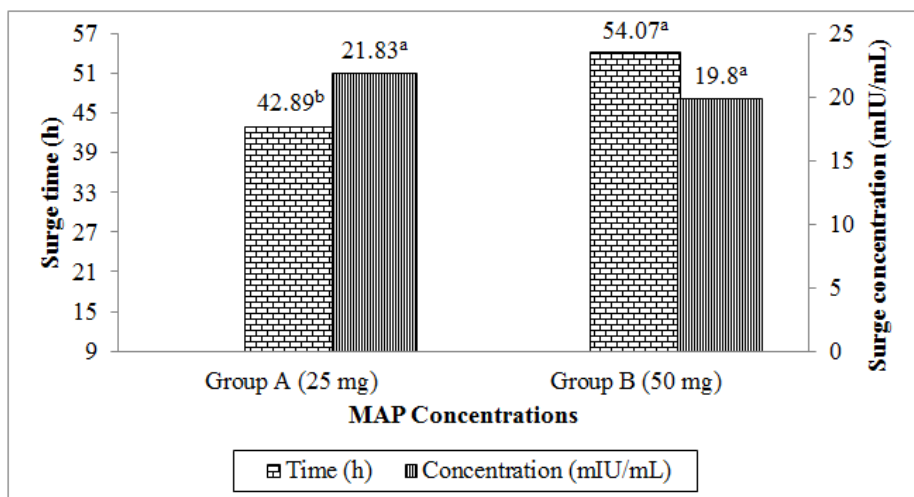

Figure 3: Effect of MAP concentration in the vaginal sponge on the peripheral circulating surges time (h) and concentration of $\mathrm{LH}(\mathrm{mIU} / \mathrm{mL})$ in ewes synchronized estrus. 
Regardless of MAP effect, figure 4 showed the mean time extended from sponge removal to $\mathrm{LH}$ surge was significantly $(\mathrm{P}<0.05)$ longer in ewes of group A1B1; control $(61.00 \pm 4.32 \mathrm{~h})$ than groups A2B2; 300 IU/eCG (47.63 $\pm 4.46 \mathrm{~h})$ and A3B3; $500 \mathrm{IU} / \mathrm{eCG}$ $(41.71 \pm 5.11 \mathrm{~h})$. The mean of LH surge concentrations were $20.56 \pm 2.13 \mathrm{mIU} / \mathrm{mL}, 20.72 \pm 2.28 \mathrm{mIU} / \mathrm{mL}$ and $20.95 \pm 2.42 \mathrm{mIU} / \mathrm{mL}$ for ewes of groups A1B1 (without eCG; control), A2B2 (300 IU/eCG) and A3B3 (500 IU/eCG), respectively with not significant differences (Figure 4).

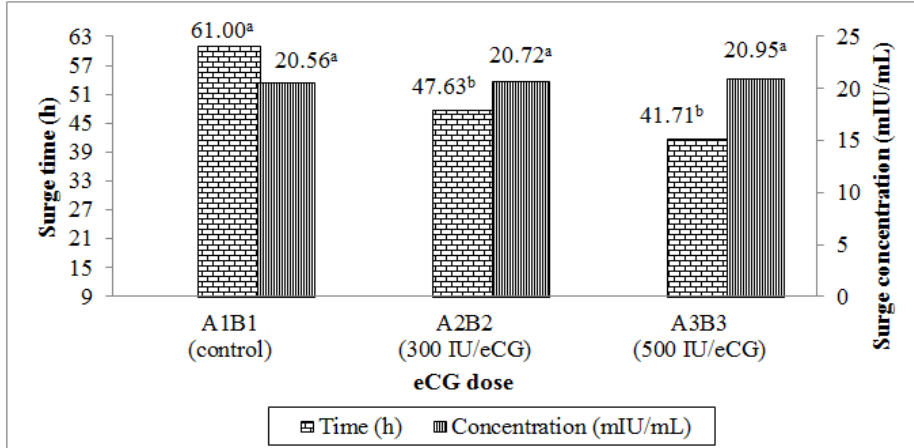

Figure 4: Effect of eCG doses on the surges time (h) and concentration (mIU/mL) of LH in ewes synchronized estrus.

Irrespective eCG effects, the time from sponge withdraw to estradiol-17 $\beta$ peak required a longer period $(\mathrm{P}<0.05)$ for ewes in-group $\mathrm{B}$ than group A $(51.13 \pm 3.90 \mathrm{~h}$ vs $40.56 \pm 4.63 \mathrm{~h}$; Figure 5). Whereas, the concentrations of estradiol-17 $\beta$ peaks were $8.90 \pm 0.76 \mathrm{pg} / \mathrm{mL}$ and $7.74 \pm 0.72 \mathrm{pg} / \mathrm{mL}$, for groups A and $\mathrm{B}$, respectively with not significant differences (Figure 5)

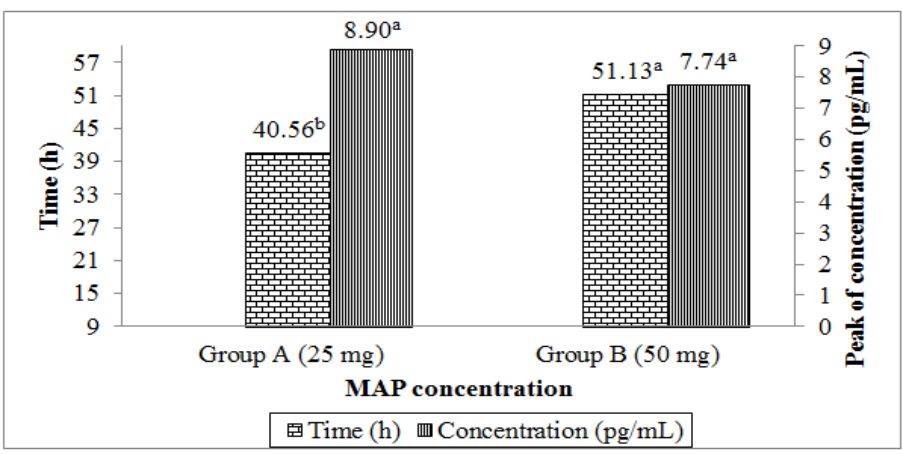

Figure 5: Effect of MAP in the vaginal sponge on the time (h) and peak concentration of plasma estradiol-17 $\beta$ $(\mathrm{pg} / \mathrm{mL})$ in ewes synchronized estrus.

The effect of eCG doses on estradiol-17 $\beta$ peak and its time and are shown in (Figure 6). The time extended from sponge removal to the peak of estradiol-17 $\beta$ was significantly $(\mathrm{P}<0.05)$ longer in ewes group A1B1 $(58.38 \pm 4.99 \mathrm{~h})$ than groups A2B2 $(44.88 \pm 4.99 \mathrm{~h})$ and
A3B3 (39.14 $\pm 5.72 h)$. In contrast, ewes of group A3B3 (11.50 $\pm 1.02 \mathrm{pg} / \mathrm{mL})$ showed higher level $(\mathrm{P}<0.01)$ of estradiol-17 $\beta$ than ewes of groups A1B1 $(6.46 \pm 0.90 \mathrm{pg} / \mathrm{mL})$ and A2B2 $(7.06 \pm 0.79 \mathrm{pg} / \mathrm{mL})$.

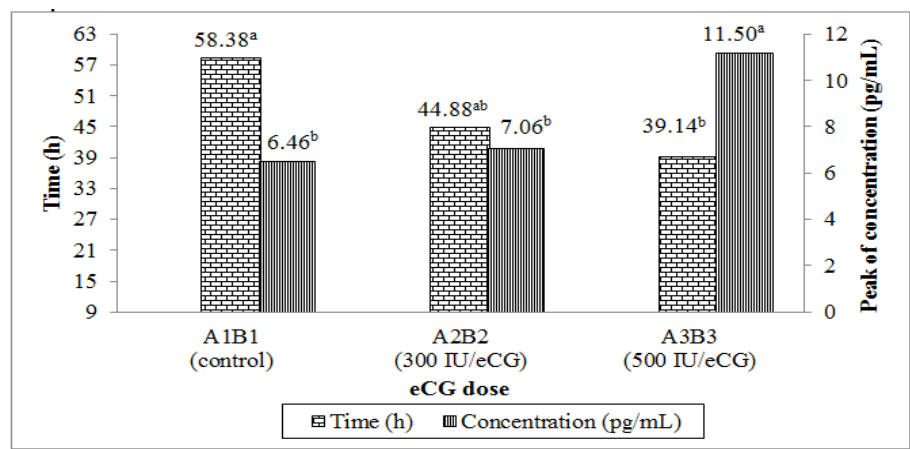

Figure 6: Effect of eCG doses on the peak concentration (pg/mL) and its time (h) of estradiol-17 in ewes synchronized estrus. 


\section{DISCUSSION}

The initial levels of plasma progesterone in both treated groups were more than $1.5 \mathrm{ng} / \mathrm{mL}$ indicates the ewes were reproductively cyclic. Similarly, Jarquin et al. (2014) found that ewes were considered reproductively cyclic before the onset of experiment as plasma progesterone concentrations higher than 1ng/mL. Accordingly, Husein and Kridi, (2002); Fleisch et al. (2012); Najafi and Cedden, (2015) found before sponges insertion, the plasma progesterone concentrations were 1.4 to $2.8 \mathrm{ng} / \mathrm{mL}$ with no significant differences among ewes groups treated with different sources of progestagens. Whatever the case, the high level of plasma progesterone at the time of sponge insert indicates that ewes were reproductively cyclic and progesterone produced from functionally CL of ewes. This possibility is compatible with Jarquin et al. (2014) they found that, before the onset of the experiment, the plasma progesterone concentrations were $>1 \mathrm{ng} / \mathrm{mL}$ in cyclic ewes. In the current study, the started level of plasma progesterone in groups $\mathrm{A} \& \mathrm{~B}$ were increased gradually following sponge insertion reaching to its maximum levels on days 8 and then rapidly decreases until reach to its minimum level on day 14 (day of sponge with draw). The results concur with previous investigations that have suggested the circulating serum progesterone levels were elevated in ewes following insertion of the CIDR device and the mean peak levels of serum progesterone were observed on Day 5 of CIDR treatment then fell to its lowest level on the final day of treatment (Satterfield, 2004; Gungor et al., 2009; Altincekic et al., 2011).

Although the plateau patterns of plasma progesterone to some extent were similar in both groups, but group A (25mg MAP) was generally slightly lower in plasma progesterone than group B (50 mg MAP) with no significant differences (Figure 1). These results are concurred with Kasikci et al. (2011) they found slightly lower in plasma progesterone levels in halved sponge group than those of the whole sponge. Additionally, they have suggested that no significant differences in the serum progesterone concentrations on days 1, 4, 7, 10, and 13 after sponge insertion. This gives an indication that the amount of MAP, which absorbed in both groups, may be approximately similar for all treated ewes. This possibility is compatible with Simonetti et al. (2000) they found the absorbed levels of MAP were not different among animal groups treated with 40, 50 or $60 \mathrm{mg}$ MAP. These researchers postulated that differences among initial doses of sponges correlate with differences among residual sponges remaining on sponges following treatment, but not with the absorbed levels. Similarly, Greyling et al. (1997) informed that the dose of progestagen in the sponge was superfluous. Furthermore, research done by Munro, (1987) compare the trends of plasma progesterone profiles between CIDR devices and progesterone releasing intra-vaginal devices (PRIDs) containing two different dosage levels. He found that, regardless of treatment type, mean progesterone levels prior to treatment were not significantly different from concentrations observed 24 and 48 hours post treatment. Upon initiation of the treatments, concentrations rose rapidly on day 1 and declined to lower level on day 14 of treatment, with no significant differences between treatments. However, contrary to this finding, Mobarak et al. (1984) found that the level of progestagen absorbed to increase as the initial dose increased.

The maximum levels of plasma progesterone reached after 6-8 days of sponge insertion in both treated groups (A \& B). Consistency, the mean peak levels of serum progesterone were observed on days 5 (Satterfield, 2004) or seven (Kaya et al., 2013) of sponge insertion, then gradually decline to lowest level on the final day of treatment. Other studies reported that, plasma progesterone concentrations sharply raised to reach its maximum level more early at one day (Hamra et al., 1986; Vinoles et al., 2001) two days (Greyling and Van der Nest, 2000) three days (Wheaton et al., 1993) after sponge insertion, then declined steadily reaching to its minimum concentration on the day of sponge with drawal. Actually the plateau of plasma progesterone in group (A) may be prospecting causes in acceleration the time to estradiol surge in group A than group B which have led to shortening the time to onset estrus in this group (36.23 vs $46.10 \mathrm{~h}$, untabulated data). Moreover, the plateau of plasma progesterone in group A was associated with higher pregnancy rate than ewes of group B (83.33 vs 65.24; untabulated data). Accordingly, Greyling et al. (1997) compared the use of whole or halved sponges and although no significant differences in plasma progesterone between the two groups, but the females treated with halved sponges had a tendency to be in estrus more sooner than those treated with whole sponges. In accordance, Haresign, (1985); Hamra et al. (1986); Scaramuzzi et al. (1988) and Menchaca and Rubianes, (2004) reported that high doses of progesterone or long term of treatment have a negative effect on oocyte development. Long-term progestagen treatment results in subluteal progesterone level (Haresign, 1985) and this phenomenon leads to increase the LH pulse's frequency, but the LH surge does not occur and result in a prolonged dominant follicle ovulate oocyte with inferior quality and less fertile, which subsequently reduces the fertility rate (Ainsworth and Downey, 1986). This depression in the conception rate also may be because of asynchrony between estrus and ovulation (Scaramuzzi et al., 1988). 
The preovulatory LH surge is a prerequisite for ovulation and occurs as a response to $\mathrm{GnRH}$ surge which released from the hypothalamus (Moenter et al., 1990; Karsch et al., 1997 and Evans et al., 1997). The acute rises of $\mathrm{LH}$ to a peak concentration in the blood (LH surge) trigger the mechanism of ovulation in sheep (Younes, 2008). Cumming et al. (1973) concluded that knowledge of the time of the LH peak had a greater predictive value of the time of ovulation than had the onset of estrus. The LH surge is highly correlated with the time of ovulation as it stimulates ovulation, which occurs about 14 hours after the LH peak, or 24 hours after the beginning of estrus (Pierson et al., 2001 and Alvarez et al., 2007). This estimation of time of ovulation could be of great assistance in timing AI or mating for maximum conception in ovine breeding programs (Ashwag et al., 2015).

Aside of eCG effects, the mean time from sponge withdraw to LH surge was significantly shorter in group A than group B. Similarly, Husein and Ababneh, (1998) recorded that the time to LH peak was significantly earlier in ewes group treated with low dose of progestagens than the high dose. The authors contributed these differences to the ewes, which treated with low dose of progesterone come into estrus more early and at the same time showed earlier estradiol-17 $\beta$ surge than the ewes which treated with high dose. Whereas, ewes treated with high dose of progesterone showed delay in onset estrus and consequently LH surge lateness and required additional time for the recruitment and maturation of the ovulatory follicle. Our results are consistent and reinforce this explanation, hence the ewes of group A showed early times to estradiol-17 $\beta$ peak and onset estrusthan group B.

The mean times extended from sponge removal to LH surge are consistent with Lahoz et al. (2013) and higher than that recorded by Godfrey et al. (1998) and Adib et al. (2014). This discrepancy may be linked to large extent with differences in the breeds, location, and management protocol. However, our results showed that as eCG doses increased the $\mathrm{LH}$ surge time decreased with no significant differences. These findings concur with previous investigations suggested that the times to LH surge ranged from 37.3 to $51 \mathrm{~h}$ after sponge removal, in ewes treated with sponges containing FGA followed by different doses of eCG, and the time to $\mathrm{LH}$ peak was significantly earlier in ewes treated with eCG than without eCG (Kaya et al., 2005; Rutigliano, 2010 and Lahoz et al., 2013).

This interpretation enhanced by Karsch et al. (1980) they suggested that, the beginning of the estrus following simulated preovulatory estradiol rise which can initiate and accelerate the LH surge in ewes. In addition, authors found tight coupling between the LH surge and the onset of estrus. Moreover, Karsch, et al. (1992); Day and Geary, (2005); Senger, (2005) mentioned that the onset of estrus is a key functions to the estradiol and Signal for inducing the surge of LH. However, the interval between the onset of estrus and the beginning of the preovulatory $\mathrm{LH}$ discharge is known to vary widely according to breed, body condition score, breeding season, number of ova shed and to depend on the dose and duration of progestagen treatment when estrus is synchronized (Salamon \& Maxwell, 1995; Keisler \& Buckrell, 1997; Menchaca \& Rubianes, 2004; Ustuner et al., 2007; Abecia et al., 2011).

Seemingly, the protocols of estrus synchronization beside its influence on the LH surge (time and level) ultimately affects the time of ovulation. The importance to have knowledge about the time of ovulation will determine the suitable time for insemination/mating to meet out the availability of sperm near ovulation for successful fertilization (Kumar and Naqvi, 2014). Barrett, et al. (2004); Vilarinoa et al. (2010); Martemucci and D'Alessandro, (2011) recorded that; the interval from sponge removal to ovulation time was earlier for ewes treated with eCG (200-500IU) than without eCG. Unfortunately, the times of ovulations were not determined in this study to confirm whether this was in fact the case.

Irrespective of eCG treatment, the concentrations of LH surge was slightly higher for group A than B with no significant differences. Similarly, Greyling et al. (1997) found that the halved MAP sponge ewes treated for 14 days had slightly higher mean LH concentrations and significantly higher conception and lambing rates compared with the whole sponge treated ewes. Referred to our results, the pregnancy rates were also higher in-group A than group B and this concurred with the previous authors. However, the lambing rates were similar for group A and B. The high progesterone concentrations during the midluteal phase of the estrous cycle decrease LH secretion, which is crucial for final growth and maturation of preovulatory follicles (GonzalezBulnes et al., 2004) and causes a variability in the timing of ovulation after luteolysis (Gonzalez-Bulnes et al., 2005). Our results are consistent with this vision where, ewes of group B which treated with high dose of MAP having relatively high concentration of plasma progesterone than group A, as well as it recorded higher level of LH surge than group A which treated with low dose of MAP.

Estradiol plays an important role and consider as a switch key from negative to positive feedback action underlying neurobiological mechanisms on both the hypothalamus and the pituitary gland in control of the estrous cycle and regulating reproductive function 
(Day and Geary, 2005). The time from sponge withdraw to estradiol-17 $\beta$ surge was significantly longer for ewes in-group B than group A, in return, the concentration of estradiol-17 $\beta$ peak was slightly higher for group A than B. Similarly, Pearce and Robinson, (1985) observed that, the time to estradiol$17 \beta$ peak was significantly longer in synchronized ewes treated with high dose of progesterone than treated with low dose. Regardless of MAP concentration, the time extended from sponge removal to estradiol-17 $\beta$ time peak was longer in ewes group A1B1 (control) than groups A2B2 (300 IU/eCG) and A3B3(500 IU/eCG). In contrast, ewes of group A3B3 showed higher level surges of estradiol-17 $\beta$ than ewes of groups A1B1 and A2B2. Similarly, Barrett et al. (2004) and Habibizad et al. (2015) found that the mean serum estradiol concentrations for the pre- and early post-ovulatory periods were higher in eCG treated ewes compared to the control group. Moreover, the higher doses of gonadotropin (400-600 IU/eCG) would presumably lead to more estrogen production (Moakhar et al., 2012 and D'Souza, 2013) from the largest follicle which is the principal source of estradiol (MunozGutierrez et al., 2002).

Irrespective to $\mathrm{eCG}$ treatment, ewes in-group $\mathrm{A}$ which showed earlier time with higher level of estradiol-17 $\beta$ were exhibited onset estrus more earlier and slightly longer of estrus duration than group B. On the other side, regarding to eCG effects, ewes in groups $\mathrm{A} 3 \mathrm{~B} 3$ and $\mathrm{A} 2 \mathrm{~B} 2$ were expressed shorter time and higher level of plasma estradiol-17 $\beta$ and associated with shorter times to onset estrus than control group (without eCG). Our findings promote interpretative statement that, the high preovulatory level of circulating estrogen is responsible for induces estrous behavior (Moakhar et al., 2012), and consequently promotes higher levels of estrogen production by the growing follicles, that improve the occurrence of estrus (Dogan and Nur, 2006). So, one would expect estrous responses to be positively correlated with estrogen concentration during the peri-estrus period (Mondal et al., 2006) as a sequel of gonadotropin doses (D’Souza, 2013). Moreover, current observation reinforce the hypothesis of Yildiz et al. (2004) they suggests that the prolonged estrus probably results in elevation of circulating estrogen that causes LH peak.

Complementing the same topic, Noor Hashida et al. (2013) showed that, eCG injections can be substituted LH/FSH of the pituitary gland which stimulate development of the ovarian follicle and consequently, leads to increase plasma estradiol-17 $\beta$ concentration and increase the number of ovulations in synchronized ewes. Further than that, serum estradiol increased after one day of sponge removal and ewes treated with eCG had greatest $(\mathrm{P}<0.05)$ concentration of estradiol produced from large follicles of ewes having two ovulations and twin births (Habibizad et al., 2015). This explains that, despite there are no significant differences in the fecundity and prolificacy rates between ewes groups in the current study, but the rates of twins increased as eCG doses increased, opposite no twins was recorded in control ewes (without eCG).

The early estradiol peak conducive leads to more coincide of estrus frequency, so more than $80 \%$ of ewes in-group A exhibited onset estrus during $48 \mathrm{~h}$ after sponge withdraw, while only $60 \%$ of ewes in group B showed estrus signs with the same period. On the other side 80,75 and $64 \%$ of ewes in groups A3B3, A2B2 and A1B1, respectively, showed estrus within $48 \mathrm{~h}$ after sponge removal. Similarly, eCG injection at the end of the progestogens treatment causes more precise synchronization of estrus (Ustuner et al., 2007), and induces a tighter synchrony of ovulation in both anestrous and cycling sheep (Dogan and Nur, 2006). Injecting eCG after CIDR removal causes estrus signs to begin earlier, become more pronounced and prolonged, this probably results in elevation of circulating estrogen that causes LH peak (Yildiz et al., 2004 and Ataman, et al., 2006).

\section{CONCLUSION}

The plateau patterns of plasma progesterone in ewes treated with $25 \mathrm{mg}$ MAP (group A) causes in acceleration the time to estradiol peak which may be the cause of shortening the time to onset estrus than group B which treated with $50 \mathrm{mg}$. Moreover, the plateau patterns in group A were associated with higher pregnancy rate. Regardless MAP concentration, eCG treatment showed higher level of estradiol-17 $\beta$ associated with early signs of estrus than untreated ewes. The mean time from sponge withdraw to LH surge was shorter and subsequently the ovulation is early in the group treated with $25 \mathrm{mg}$ MAP and co-treated with eCG, so insemination should be more early in these groups. This mean, the plateau patterns of circulating reproductive hormones is affected by the protocols used for estrus synchronization in sheep and subsequently could affects reproductive performance.

\section{ACKNOWLEDGEMENTS}

The authors wish to thank Dr. Abdel Karim Mahmoud for his assistant for pregnancy diagnosis throughout the experiment using ultrasonography.

\section{REFERENCES}

Abecia, J.A.; Forcada, F. and Gonzalez-Bulnes, A. (2011): Pharmaceutical Control of Reproduction in Sheep and Goats. Vet. Clin. Food Anim. Prac., 27: 67-79. 
Adib, A.; Freret, S.; Touze, J.; Lomet, D.; Lardic, L.; Chesneau, D.; Estienne, A.; Papillier, P.; Monniaux, D. and Rubio, M. (2014): Progesterone improves the maturation of maleinduced preovulatory follicles in anoestrous ewes. Reproduction, (148), 403-416.

Ainsworth, L. and Downey, B.R. (1986): A Controlled Internal Drug-Release Dispenser Containing Progesterone for Control of the Estrous Cycle of Ewes. Theriogenology, 26 [6], 847-857.

Altıncekic, Ş.O.; Koyuncu, M.; Tuncel, E. and Kaymakcı, M. (2011): Kıvırcık Koyunlarında Uremenin Mevsime Bağlılığıve Östrus Boyunca Östradiol-17 $\beta$ ve Progesteron Hormonu Duzeylerinin Değişimi. Hayvansal Üretim., 52(2): 10-19.

Alvarez, L.E.M.; Ceron, J.H.; Padilla, E.G.; Marın G.P. and Valencia, J. (2007): Serum LH peak and ovulation following synchronized estrus in goats. Small Ruminant Research. (69): 124128.

Amer, H.A. and Hazzaa, A.M. (2009): The effect of different progesterone protocols on the reproductive efficiency of ewes during the non-breeding season. Veterinarski Arhiv. 79 (1): 19-30.

Ashwag, E.M. and Mohamed Nour, M.S. (2015): chronological relationships between Estrus onset, time of LH surge and Ovulation time in does synchronized Withchronogest or CIDR. International Journal of Technical Research and Applications e-ISSN: 2320-8163.

Ashwag, E.M.; Mohamed Nour, M.S. and Ghurashi, M.A.H. (2015): Chronological relationships between oestrus onset, time of LH surge and ovulation time in does synchronized using fluorogestone with different doses of eCG. Res. Opin. Anim. Vet. Sci., 5(4): 183-188.

Ataman, M.B.; Akoz, M. and Akman, O. (2006): Induction of synchronizedoestrus in akkaraman cross-bred ewes during breeding and anestrus seasons: the use of short-term and long-term progesterone treatments, Revue Méd. Vét. 157(5): 257-260

Barrett, D.M.; Bartlewski, P.M.; Batista-Arteaga, M.; Symington, A. and Rawlings, N.C. (2004): Ultrasound and endocrine evaluation of the ovarian response to a single dose of 500 IU of eCG following a 12-day treatment with progestagen-releasing intravaginal sponges in the breeding and nonbreeding seasons in ewes. Theriogenology; 61, 311-327.

Bartlewski, P.M.; Beard, A.P. and Rawlings, N.C. (1999): The relationship between vaginal mucous impedance and serum concentrations of estradiol and progesterone throughout the sheep estrous cycle. Theriogenology 51, 813827.

Crosby, T.F.; Boland, M.P. and Gordon, I. (1991): Effect of progestagen treatments on the incidence of estrus and pregnancy rates in ewes. Anim. Reprod. Sci. 24:109-118.

Cumming, I.A.; Buckmaster, J.M.; Blockley, M.A.; Goding, J.R.; Winfield, C.G. and Baxter, R.W. (1973): Constancy of interval between luteinizing hormone release and ovulation in the ewe. Biol. Reprod. 9, 24-29.

D'Souza, K.N. (2013): Effects of a Gonadotropin Mixture on Reproductive Success in Progesterone-Treated Non-Lactating Anestrous Ewes. Master of Science in Reproductive Physiology: UMI Number: 1524600, USA.

Day, M.L. and Geary, T.W. (2005): Handbook of Estrous Synchronization. The Ohio State University, Western Region Publication No. 14.

Dogan, I. and Nur, Z. (2006): Different estrous induction methods during the nonbreeding season in Kivircik ewes. Vet. Med.; 51(4): 133-138

El-Wakil, Salwa, I.; Shemeis, A.R.; Ahmed, A.M. and Abdallah, O.Y. (2008): Genetic and phenotypic relationships involving body weight, degree of maturity and measurer of gain rate of Barki sheep without having recourse to fitting growth curves. J. Agric. Sci. Mansoura Univ., 33: 4835-4848.

Evans, N.P.; Dahl, G.E.; Padmanabhan, V.; Thun, L.A. and Karsch, F.J. (1997): Estradiol requirements for induction and maintenance of the gonadotropin-releasing hormone surge: implications for neuroendocrine processing of the estradiol signal. Endocrinology; 138:54085414.

Fleisch, A.; Werne, S.; Heckendorn, F.; Hartnack, S.; Piechotta, M.; Bollwein, H.; Thun, R. and Janett, F. (2012): Comparison of 6-day progestagen treatment with Chronogest ${ }^{\circledR} \mathrm{CR}$ and Eazi-breed CIDR- G intravaginal inserts for estrus synchronization in cyclic ewes. Small Ruminant Research 107, 141-146.

Godfrey, R.W.; Collins, J.R.; Hensley, E.L. and Wheaton, J.E. (1998): Estrus synchronization and artificial insemination of hair sheep ewes in the tropics. Theriogenology, 51: 985-997.

Gonzalez-Bulnes, A.; Souza, C.J.; Campbell, B.K. and Baird, D.T. (2004): Systemic and intraovarian effects of dominant follicles on ovine follicular growth. Anim. Reprod. Sci. 84, 107-119.

Gonzalez-Bulnes, A.; Veiga-Lopez, A.; Garcia, P.; Garcia-Garcia, R.M.; Ariznavarreta, C.; Sanchez, M.A.; Tresguerres, J.A.F.; Cocero, M.J. and Flores, J.M. (2005): Effects of progestagens and prostaglandin analogues on ovarian function and embryo viability in sheep. Theriogenology 63, 2523-2534.

Greyling, J.P.C. and Van der Nest, M. (2000): Synchronization of estrous in goats: dose effect of progestagen. Small Rumin Res.; 36: 201207. 
Greyling, J.P.C.; Erasmus, J.A.; Taylor, G.J.; Van der Merwe, S. (1997): Synchronization of estrus in sheep using progestagen and inseminating with chilled semen during the breeding season. Small Rumin. Res.; 26: 137143.

Gungor, O.; Ozyurtlu, N.; Pancarci, S.M.; Kaya, M.; Zonturlu, A.K.; Oral, H.; Cetin, Y. and Polat, $B$. (2009): Estrous synchronization with used CIDR-G devices in ewes during non-breeding sea-son. Kafkas Univ. Vet. Fak. Derg. 15, 779783.

Habibizad, J.; Riasi, A.; Kohram, H. and Rahmani, H.R. (2015): Effect of feeding greater amounts of dietary energy for ashort-term with or without eCG injection on reproductive performance, serum metabolites and hormones in ewes. Animal Reproduction Science, Volume 160, pages: 82-89.

Hamra, A.H.; Massri, Y.G.; Marcek, J.M. and Wheaton, J.E. (1986): Plasma progesterone levels in ewes treated with progesteronecontrolled internal drug-release dispensers, implants and sponges. Anim Reprod Sci; 11: 187-194.

Haresign, W. (1985): Comparison of the rate of decline in plasma progesterone concentrations at a natural and progesterone-synchronized oestrus and its effect on tonic $\mathrm{LH}$ secretion in the ewe. J.Rprod.Fert.75, 231-236.

Husein, M.Q. and Kridi, R.T. (2002): Reproductive responses of Awassi ewes treated with either naturally occurring progesterone or synthetic progestagen. Asian-Australian J. Anim. Sci. 9, 1257-1262.

Husein, M.Q. and Ababneh, M.M. (2007): A new strategy for superior reproductive performance of ewes bred out-of-season utilizing progestagen supplement perior to withdrawal of intra vaginal pessaries. Arab Organization for Agricultural Development. Jordan, 176:199.

Husein, M.Q.; Bailey, M.T.; Ababneh, M.M.; Romano, J.E.; Crabo, B.G. and Wheaton, J.E. (1998): Transcervical artificial insemination of ewes out-of season using frozen-thawed semen Effect of equine chorionic gonadotropin on pregnancy rate. Theriogenology, 49: 997-1005.

Jarquin, S.; Roldan, A.; Zarco, L.; Berruecos, J. and Valencia, J. (2014): Effect of stage of the estrous cycle at the time of initial exposure to rams on the ovarian activity of Pelibuey ewes. Czech J. Anim. Sci., 59(11): 504-510.

Karasch, F.J.; Bowen, J.M.; Caraty, A.; Evans, N.P. and Moenter, S.M. (1997): Gonadotropinreleasing hormone requirements for ovulation. Biol. Reprod. 56, 303-309.

Karsch, F.J.; Legan, S.J.; Ryan, K.D. and Foster, D.L. (1980): Importance of estradiol and progesterone in regulating $\mathrm{LH}$ secretion and estrous behavior during the sheep estrous cycle. Biol. Reprod. 23:404-413.

Karsch, F.J.; Moenter, S.M. and Caraty, A. (1992): The neuroendocrine signal for ovulation. Animal Reproduction Science 28 329-341.

Kasikci, G.; Cirit, U.; Gunduz, M.C.; Bacinoglu, S. and Sabuncu, A. (2011): Effects of halving intravaginal sponges and eCG dose on estrus response and fertility in Tahirova ewes during the breeding season. Turk. J. Vet. Anim. Sci. 35(3): 193-199.

Kaya, M.; Yildiz, S. and Guven, B. (2005): The determination of plasma progesterone, oestradiol- $17 \beta$ and luteinizing hormone levels during oestrous period of Tuj ewe-lambs following oestrus induction. Revue Méd. Vét., 156, 12, 628-632.

Kaya, S.; Kacar, C.; Kaya, D. and Aslan, S. (2013): The effectiveness of supplemental administration of progesterone with $\mathrm{GnRH}$, hCG and PGF2_ on the fertility of Tuj sheep during the non-breeding season. Small Ruminant Research 113; 365-370.

Keisler, D.H. and Buckrell, B.C. (1997): Breeding strategies. In: Youngquist R.S. (ed.): Current Therapy in Large Animal Theriogenology. WB Saunders and Co., Philadelphia. 603-611.

Kennedy, D. (2012): Sheep Reproduction Basics and Conception Rates. Order no. 12-037 Agdex 433/30.

Kumar, D. and Naqvi, S.M.K. (2014): Effect of time and depth of insemination on fertility of Bharat Merino sheep inseminated trans-cervical with frozen-thawed semen. Journal of Animal Science and Technology, 56:8.

Kusina, N.T.; Tarwirei, F.; Hamudikuwanda, H.; Agumba, G.; Mukwena, J. (2000): A comparison of the effects of progesterone sponges and ear implants, PGF2alpha, and their combination on efficacy of estrus synchronization and fertility of Mashona goat does. Theriogenology.53: 1567-1580.

Lahoz, B.; Folch, J.; Sanchez, P. and Alabart, J.L. (2013): Characterization of the preovulatory LH surge in Rasa Aragonesa sheep or allele carriers FecXR (ROA®) (ROA®). ITEA, 109 (4), 415-428.

Martemucci, G. and D'Alessandro, A.G. (2011): Synchronization of oestrus and ovulation by short time combined FGA, PGF2, GnRH, eCG treatments for natural service or AI fixed-time. Animal Reproduction Science 123;32-39.

Menchaca, A. and Rubianes, E. (2004): New treatments associated with timed artificial insemination in small ruminants. ReprodFertil Develop, 16, 403-413.

Moakhar, H.K.; Kohram, H.; Shahneh, A.Z. and Saberifar, T. (2012): Ovarian response and pregnancy rate following different doses of 
eCGtreatment in Chall ewes. Small Ruminant Research;102, 63-67.

Mobarak, M.S.; McDonnell, H. and Gordon, I. (1984): The use of progesterone impregnated sponges in intact cyclic ewes bred by natural and artificial insemination. In: Research Report 1982-1983, Faculty of General Agriculture, University College, Dublin; 101-108.

Moenter, S.M.; Caraty, A. and Karsch, F.J. (1990): The estradiol-induced surge of gonadotropinreleasing hormone in the ewe. Endocrinology; 127: $1375-1384$.

Mohammed, KM.; Farag, BF.; Daghash, HS. And Azab, MM. (2016): Effect of estrus synchronization protocols on the reproductive performance of Barki sheep. Assuit Vet. Med. J. vol. 62; No. 151, 22-35.

Mondal, M.; Rajkhowa, C. and Prakash, B.S. (2006): Relationship of plasma estradiol-17b, total estrogen and progesterone to estrous behavior in mithun (Bosfrontalis) cows. Horm Behav 49, 626-633.

Moradi Kor, N.; Khanghah, K.M. and Ali Veisi, A. (2013): Follicular Fluid Concentrations of Biochemical Metabolites and Trace Minerals in Relation to Ovarian Follicle Size in Dairy Cows. Annual Review and Research in Biology 3(4): 397-404.

Munoz-Gutierrez, M.; Blache, D.; Martin, G.B. and Scaramuzzi, R.J. (2002): Folliculogenesis and ovarian expression of mRNA encodingaromatase in anoestrous sheep after 5 days of glucose orglucosamine infusion or supplementary lupin feeding. Reproduction; 124, 721-731.

Munro, R.K. (1987): Concentrations of plasma progesterone in cows after treatment with 3 types of progesterone pessaries. Aust. Vet. J.; 64: 283-284.

Najafi, G.h. and Cedden, F. (2015): Ovarian hormones in Ghezel ewes treated with pregnant mare serum gonadotropin (PMSG) during the breeding season. I.J.A.L.S., Volume (8); 139-144, Issue (2)

Noor Hashida, Syafnir, H. and Meriksa, S. (2013): Time of PMSG administration: Effect on progesterone and estradiol concentration in synchronized ewes. Biomedical Research., 24 (1): 7-12.

Pearce, D.T. and Robinson, T.J. (1985): Plasma progesterone concentrations, ovarian and endocrinological responses and sperm transport in ewes with synchronized oestrus. J. Reprod. Fert. 75, 49-62.

Pierson, J.T.; Baldassarre, H.; Keefer, C.L. and Downey, B.R. (2001): Seasonal variation in preovulatory events associated with synchronization of estrus in dwarf goats. Theriogenology. 56: 759-769.

Rutigliano, H.M. (2010): Using Single Chain Gonadotropins to Enhance Fertility in Sheep.
This is a doctoral of philosophy in Animal Biology, university of California, UMI Number: 3427407.

Salamon, S. and Maxwell, W.M.C. (1995): Frozen storage of ram semen. Causes of low fertility after cervical insemination and methods of improvement. Animal Reproduction Science, 38: 1-36.

Salleh, S.M.; Yaakub, H. and Panandam, J.M. (2014): Progesterone and Luteinising Hormone Profile of Saanen Crossbred Goats Synchronised with CIDR and PMSG. Mal. J. Anim. Sci. 17(1): 95-102.

Sareminejad, P.; Tabatabaei, S.; Maтоиеi, M.; Mirzadeh, K. and Boujarpour, M. (2014): The Effects of Short and Long Term Medroxy Progesterone Acetate (MAP) Sponge Treatments on Reproductive Performance during the Non-Breeding Season of Arabian Ewes. Iranian Journal of Applied Animal Sci.; 4(4), 747-751.

Satterfield, M.C. (2004): Evaluation of the effect of progesterone cidr devices on circulating levels of progesterone in cyclic ewes. Master of science, Texas A\&M University.

Scaramuzzi, R.J.; Downing, J.A.; Campbell, B.K. and Cognie, Y. (1988): Control of fertility and fecundity of sheep by means of hormonal manipulation. Aust. J. Biol. Sci. 41: 37-45.

Senger, P.L. (2005): Pathways to pregnancy and Parturation. 2nd revised edition, Current Conceptions, Inc., Pullman.

Simonetti, L.; Blanco, M.R. and Gardoan, J.C. (2000): Estrus synchronization in ewes treated with sponges impregnated with different doses of medroxyprogesterone acetate. Small Ruminant Research 38: 243-247.

Ungerfeld, R. (2003): Reproductive responses of anestrous ewes to the introduction of rams. Doctoral thesis. ISSN 1401-6257.

Ustuner, B.; Gunay, U.; Nur, U. and Ustuner, U. (2007): Effects of long and short-term progestogens treatment combined with PMSG on oestrus synchronization and fertility in Awassi ewes during the breeding season. Journal of ActaVeterinaria Brno. 76:391-397.

Van Cleeff, J.; Karsch, F.J. and Padmanabhan, V. (1998): Characterization of endocrine events during the periestrous period in sheep after estrous synchronization with controlled internal drug release (CIDR) device. Domest Anim Endocrinol; 15:23-34.

Vilarinoa, M.; Rubianes, E.; van Lier, E. and Menchaca, A. (2010): Serum progesterone concentrations, follicular development and time of ovulation using a new progesterone releasing device (DICO®) in sheep. Small Ruminant Research; 91, 219-224.

Vinoles, C.; Forsberg, M.; Banchero, $G$. and Rubianes, E. (2001): Effect of long-term and short-term progestagen treatment on follicular 
development and pregnancy rate in cyclic ewes. Theriogenology, 55, 993-1004.

Wheaton, J.E.; Carlson, K.M.; Windels, H.F. and Johnston, L.J. (1993): CIDR a new progesterone-releasing intravaginal device for induction of estrus and cycle control in sheep and goats. Anim. Reprod. Sci. 33, 127-141.

Yavuzer, U. (2005): The possibilities of twice yearly lambing of Awassisheep ewes without using hormones in an organic animal production system. Turk. J. Vet. Anim. Sci. 29: 27-30.
Yildiz, S.; Uzun, M.; Kaya, M.; Ucar, O. and Genesiz, $O$. (2004): Effects of rams and luteal or follicular phase ewes on preovu-latory $\mathrm{LH}$ surge characteristics in ewes. Turk. J. Vet. Anim. Sci. 28, 669-673.

Younes, M. (2008): A comparison of ovarian function in juvenile and adult ewes using in vitro culture and proteomics. Aberystwyth: Aberystwythuniversity; 302P.

\section{المستويات الهرمونية في بلازما الام المصاحبة للتزامن الثبقى باستخدام تركيزات مختلفة من البروجستيرون اسيتات وهرمون الجونادوتروفين فى الأغنام البرقى تركئ كامل مصطفى محمد ، بلال فراج فرج ، حسن داغش ، محد عزب عوض الله}

